\section{Spontaneous bacterial peritonitis} in the medical intensive care unit of a University Hospital in Egypt: frequency, bacteriological profile, risk factors and outcomes

\section{Abstract}

Objective: To assess the frequency of spontaneous bacterial peritonitis (SBP) in the Medical intensive care unit (ICU) of Zagazig University Hospital, identify the causative organisms, their susceptibility to antimicrobials, and to determine risk factors and clinical outcomes.

Methods: One hundred and eighty-nine ascitic patients suffered of liver cirrhosis were included in this prospective study. Medical history, physical examination, radiological reports and assessment of disease severity were done. Diagnostic paracentesis was performed. Ascitic fluid was subjected to chemical, hematological and bacteriological investigations. Isolated bacteria and their antibiotic susceptibility pattern were identified using standard methods.

Results: Frequency of SBP in ascitic patients due to liver cirrhosis was $56.1 \%$. Classic SBP was diagnosed in $47.2 \%$ of cases and the remaining $52.8 \%$ were found to be culture negative neutrocytic ascites (CNNA). Comparison of the mean \pm standard deviation (SD) of clinical and demographic characteristics for SBP versus non SBP revealed significant association with hepatocellular carcinoma (HCC) and with beta blockers(BB). Comparison between mean \pm SD of clinical, biochemical and microbiological characteristics for SBP variants revealed significant association with HCC, total leucocytic count and positive culture. Significant symptoms and signs were observed with fever, hypotension and abdominal pain. E-coli was the most frequently isolated bacteria (56\%), followed by Klebsiella pneumoniae $24 \%$ and Staphylococcus aureus 20\%. Gentamicin was the most effective antibiotic in- vitro against $K$. pneumonia and $E$. coli isolates, while all S.
Monkez M. Yousef', Ahmed I. Amer', Ayaat M. Zidan', Fatma A. Amer', Rehab M. ElsaidTash ${ }^{2}$

$\begin{array}{ll}1 & \text { Internal Medicine Department. } \\ 2 & \text { Medical Microbiology and Immunology } \\ \text { Department, Faculty of Medicine, } \\ \text { Zagazig University, Zagazig, Egypt. }\end{array}$

Corresponding author:

Fatma A. Amer

इ" egyamer@yahoo.com 
aureus isolates were susceptible for vancomycin. Higher mortality rate was found in patients with SBP versus those with non-SBP $(p=0.024)$. Predictors of mortality among patients with SBP were related to old age and high End-Stage Liver Disease according to MELD score.

Conclusion: SBP is frequently encountered in the medical ICU as a life threatening complication of liver cirrhosis. Early diagnosis and prompt management guarantee improved prognosis.

Keywords: Spontaneous bacterial peritonitis, Neutrocytic ascites, bacterial agents \& antibiotic resistance

\section{Introduction}

Spontaneous bacterial peritonitis (SBP) is a common and severe complication of cirrhotic patients with ascites characterized by spontaneous infection of ascitic fluid which occurs in the absence of any infection or perforation of intra- abdominal organs [1]. Most episodes of SBP are caused by gram-negative bacteria, but in hospital setting, gram positive-bacteria have been isolated with an increasing frequency in recent years. Antimicrobial activity of the ascitic fluid plays very important role in the development of SBP [2].The clinical spectrum of SBP is very variable and relatively low percentage of patients show the complete typical features of acute peritoneal infection with diffuse abdominalpain, rebound tenderness, and reduced bowel sounds. Fever is a frequent but not universal finding. However, it may be the only clinical sign in a large proportion ofpatients. In other cases, infection is manifested by hepatic encephalopathy (HE), worsening of liver and/or renal function or septic shock, while the peritoneal signs maybe weak or absent. In approximately $13 \%$ of cases, SBP is asymptomatic [3]. A sample of ascitic fluid should be obtained routinely in all patients with cirrhosis and ascites admitted to hospital and in those hospitalized patients who develop signs or symptoms suggestive of SBP. The diagnosis of SBP is made when total white cell count in the peritoneal fluid is greater than 500/ $\mathrm{mm}^{3}$ and polymorph nuclear leucocyte count (PMN) is greater than $250 / \mathrm{mm}^{3}$. A positive bacterial culture of the ascitic fluid is not required for the diagnosis of SBP [4]. When the ascitic fluid PMN are morethan $250 / \mathrm{mm}^{3}$ and the ascitic fluid culture is positive, the case is identified as culture positive/classic SBP, if the ascitic fluid PMN are more than $250 / \mathrm{mm}^{3}$ and the ascitic fluid culture is negative, the condition is identified as culture negative neutrocytic ascites (CNNA) and when ascetic fluid PMN are less than $250 / \mathrm{mm}^{3}$ and the ascitic fluid culture is positive, the case is diagnosed as bacterial ascites[5].Treatment of spontaneous bacterial peritonitis has to be started immediately after diagnosis and therefore is usually empirical since culture results are not available at this time point. However, none of the international guidelines to date differentiates between nosocomial and community-acquired SBP with regard to their antibiotic treatment. This may be associated with serious consequences since nosocomial infections are associated with high rates of multiresistant bacteria and mortality [6]. The efficacy and role of prophylactic antibiotics is highly impotant [7]. 
Epidemiological studies about SBP in medical ICUs in Sharkia Governorate are scarce. To the best of our knowledge there is no study about the magnitude of this problem in our hospital. Therefore, this study has been done to assess the frequency of SBP and its variants in the Medical ICU of Zagazig University Hospital, to identify the causative bacterial flora and their susceptibility profile to antimicrobials, and to determine risk factors for acquisition of this clinical condition. Another objective was to assess the clinical outcomes; and to determine their predictors.

\section{Patients and Methods}

A total of 189 patients hospitalized in the medical ICU of the Internal Medicine Department of Zagazig University Hospital were enrolled in this cross sectional study.

This hospital is a university-affiliated and located in Zagazig city; the capital of Sharkya Governorate in the eastern province of Egypt.

Informed written consent was obtained from each enrolled case, and approval for conducting the study was obtained from the Institutional Review Board, Zagazig Faculty of Medicine. Inclusion criteria included diagnosis of ascites with complicating liver cirrhosis, and age of $\geq 18$ years. Exclusion criteria included antibiotic use in the previous two weeks, failure to obtain ascitic fluid specimen, refusal of patients to participate in the study and incomplete patients' data (biochemical, clinical). A complete medical history was collected from each patient. Data included personal history, signs and symptoms (fever, abdominal pain, GIT bleeding, HE), medications (proton pump inhibitors "PPI" and beta- blockers in the previous two weeks), and underlying diseases (e. g., diabetes, mellitus, ischemic heart disease, chronic obstructivepulmonary disease and renal disorders). All the patient were subjected to thorough physical examination with emphasize being placed on abdominal examination, routine laboratory investigations and radiological studies. Disease severity was assessed using Child -Pugh score and modified Child-Pugh classification of severity of liver disease [8], and MELD score. Paracentesis was carried out using a 23-gauge sterile needle under local anesthesia with lidocaine. Ascitic fluid samples were collected under complete aseptic technique. Ten $\mathrm{ml}$ of the fluid was inoculated immediately into aerobic and anaerobic blood culture bottles (Oxoid, Signal Blood Culture System)) at the bedside. Two $\mathrm{ml}$ of blood was added to an EDTA vacutainers (Tradekey, Egypt) to test for gross appearance, cell counts and differential count and two ml were added to a heparinized tube for chemistry testing [9].Subcultures of the blood culture bottles were made on blood agar and MacConkey'sagar (Oxoid Basingstoke, UK) and were incubated aerobically and anaerobically at $37^{\circ} \mathrm{C}$ for 24 hours. Growing colonies were identified by conventional microbiologic tests, and by API 20 E (Bio-Merieux, France) for gram negative aerobic bacilli. All isolated strains were tested for antimicrobial sensitivity test by standardized disk diffusion technique [10]. The following antibiotics were used: amikacin 30 ug, amoxicillin/clavulinate 20/10 ug, ampicillin/sulbactam 10/10 ug, azteronam 30 ug, cefepime 30 ug, cefotaxime 30 ug,ceftazidime 30 ug, ceftriaxone $30 \mathrm{ug}$, cefuroxime $30 \mathrm{ug}$, gentamycin $10 \mathrm{ug}$, imipenem10 ug and meropenem 10 ug.

Statistical Analysis: Data were collected, entered and checked to SPSS program version 17. Data were expressed as mean \pm standard deviation in quantitative variables, number and percentage for qualitative variables.Categorical data were compared using the chi-square test or fisher's exact test and are expressed as percentage. Statistical significance was defined as $P$ less than 0.05 . Continuous covariates that were not normally distributed were categorized using standard quartiles.The logistic regression model was used to perform both the univariate and multivariate analysis to examine associations between outcomes and clinical and biochemical variable. 


\section{Results}

A total of 189 patients were the subject of this study, 118 were males and 71 were females. Their ages ranged from 30- 94 years, and 67 were smokers. MELD score ranged from 6- 54, and 102 had associated infection. Random blood glucose level (mean \pm SD) was 184.5 \pm 105 (Table 1). All other Risk factors, signs and symptoms and biochemical and hematological analysis of ascitic fluid are shown in Table 1. Out of the 189 patients with ascites due to liver cirrhosis, 106 were diagnosed as SBP; 50 were classic SBP and 56 were CNNA. Biological characteristics of ascitic fluid samples in patients with SBP and number and type of each bacterial isolates are shown in Table 2 . Gentamicin was the most effective antibiotic in- vitro against K. pneumonia and E. coli, while S. aureus. was $100 \%$ susceptible to vancomycin. The susceptibility of tested antibiotics is shown in Table 3. When the mean \pm SD of clinical and demographic characteristics for SBP and non-SBPwere compared, 36.6\% of patients had hepatocellular carcinoma; $63.6 \%$ of them were having SBP and $32.4 \%$ were negative. Beta blockers were used by $21.7 \%$ of study group, mainly by those diagnosed to have non SBP. Patients with SBP were more likely to presentwith fever than those withnon SBP, whereas the latter group of patients were morelikely to present with hypotension than the former group. The rest of compared variableare shown in Table 4. Comparison between characteristics of SBP variants showed that mortality is higher in patients with SBP versus non-SBP. No statisticallysignificant difference occurred between SBP and non-SBP regarding ICU stay. The univariate analysis for risk factors for mortality among SBP patients revealed thatage andMELDscore were the only significant factors for mortality ( $p 0.001$ and $p 0.003$, respectively). When the two variables were introduced into a multivariate regressionmodel, they remained as independent risk factor for mortality (Table 4). Comparison of most important clinical,
Table I. Clinical and demographic characteristics and outcomes of study population

\begin{tabular}{|c|c|}
\hline Characteristics & $\begin{array}{l}\text { Total patients } \\
\text { No=189 }\end{array}$ \\
\hline $\begin{array}{l}\text { Sex } \\
\text { Male: N (\%) } \\
\text { Female: N (\%) }\end{array}$ & $\begin{array}{l}118(62.4) \\
71(37.6)\end{array}$ \\
\hline Age(years) mean \pm SD (range) & $60.3 \pm 13(30-94)$ \\
\hline Smokers: N (\%) & $67(35.4)$ \\
\hline MELD score mean \pm SD (range) & $21.3 \pm 9.7(6-54)$ \\
\hline Associated infection: N (\%) & $102(54)$ \\
\hline $\begin{array}{l}\text { Random blood glucose }(\mathrm{mg} / \mathrm{dl}) \\
\text { mean } \pm \text { SD }\end{array}$ & $184.5 \pm 105$ \\
\hline $\begin{array}{l}\text { Risk factors: } \\
\text { HCC: N (\%) } \\
\text { PPI: N (\%) } \\
\text { BB: N (\%) } \\
\text { Diabetes: N (\%) }\end{array}$ & $\begin{array}{l}71(36.6) \\
12(6.3) \\
41(21.7) \\
67(35.4)\end{array}$ \\
\hline $\begin{array}{l}\text { Signs and symptoms: } \\
\text { Fever: N (\%) } \\
\text { Abdominal pain: N (\%) } \\
\text { Gl bleeding: N (\%) } \\
\text { HE: N (\%) } \\
\text { Hypotension at presentation: N (\%) }\end{array}$ & $\begin{array}{l}88(46.6) \\
78(41.3) \\
23(12.2) \\
42(22.2) \\
31(16.4)\end{array}$ \\
\hline 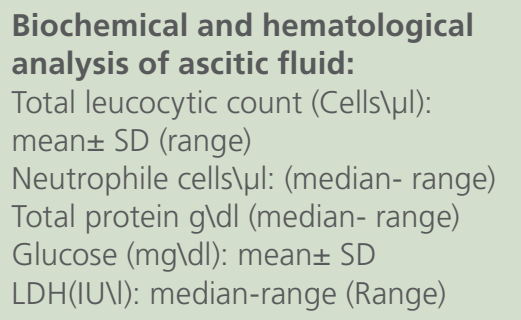 & $\begin{array}{l}925.8 \pm 1232(100-8000) \\
170(25-2200) \\
1320(71-8800) \\
174.7 \pm 113 \\
110(30-914)\end{array}$ \\
\hline Child-Pugh score: mean \pm SD (range) & $9.7 \pm 2.3(7-15)$ \\
\hline $\begin{array}{l}\text { Prothrombin time(seconds): } \\
\text { mean } \pm \text { SD }\end{array}$ & $18.1 \pm 6.7$ \\
\hline Pro Time INR (mean \pm SD) & $1.5 \pm 0.6$ \\
\hline Mortality: N (\%) & $52(27.5)$ \\
\hline ICU stay(days):mean \pm SD(Range) & $5.4 \pm 1.8(3-9)$ \\
\hline
\end{tabular}

Abbreviations; MELD: Model for End stage Liver Disease, PPI: proton pump inhibitor, HCC: hepatocellular carcinoma, BB: beta blocker, Gl: gastro-intestinal, HE: hepatic encephalopathy

biochemical and microbiological characteristics for SBP variants is shown in Table $\mathbf{5}$. 
Table 2. Biological characteristics of ascitic fluid in patients with SBP

\begin{tabular}{|c|c|}
\hline Characteristics & $\begin{array}{c}\text { SBP No=106 } \\
\text { mean } \pm \text { SD }\end{array}$ \\
\hline \begin{tabular}{l} 
Total leucocytic count in ascitic \\
sample (cells\} | \mu l ) \text { : median-range } & $900(500-8000)$ \\
\hline \begin{tabular}{l} 
Neutrophil count (cells\} \backslash \mu | ) \text { : } $\\
{\text { median-range }}$ & $450(250-2200)$ \\
\hline Total protein (mgldl): median-range & $1381(71-8800)$ \\
\hline Glucose (mgldl): mean \pm SD & $176 \pm 120$ \\
\hline LDH (IUVI): median-range & $111(30-914)$ \\
\hline $\begin{array}{l}\text { Causative bacteria isolates } \\
\text { E. coli: N (\%) } \\
\text { Klebsiella: N (\%) } \\
\text { Staph. aureus: N (\%) }\end{array}$ & $\begin{array}{l}28(56) \\
12(24) \\
10(20)\end{array}$ \\
\hline
\end{tabular}
\end{tabular}
\end{tabular}

\section{Discussion}

Spontaneous bacterial peritonitis (SBP) is one of the most common and life-threatening problems of liver cirrhosis. The frequency of SBP in patients admitted to our Medical ICU with ascites and complicating liver cirrhosis is $56.1 \%$. Remarkably, this rate is higher than rates from other parts of the world $[1,11,12]$.
Cases of SBP encountered in this work where either the classical or CNNA type, which goes in accord with the findings of Iqbal et al [11]. Our rates of the classical and the CNNA types are also comparable to those estimated by Amjad et al. (13), and Nepal et al. (14). Concerning bacterascitis type; whereas no cases were diagnosed during the current work, it has been stated to range between $3.7 \%$ and $11.1 \%$ in other studies (13-14). Differences in the occurrence of bacterascitic cases may be due to differences in the severity of the underlying liver disease or in timing of paracentesis or culture methods.

Investigations are required for accurate diagnosis. The first step is diagnostic paracentesis. Ascitic fluid culture is also needed to identify the causative agents.

Dissimilar to secondary peritonitis, SBP are usually monomicrobic [15]. The predominance of gramnegative bacteria in our work coincides with other reports [16]. These results support the theory of bacterial translocation as the most probable mechanism responsible for the occurrence of SBP in cirrhotic ascitic patients. Translocation of intestinal bacteria is somewhat organism-specific; gram-negative bacteria translocate more efficiently than gram-positive bacteria or anaerobes [17].

Table 3. Antibiotic susceptibility of the isolated bacteria

\begin{tabular}{|c|c|c|c|c|c|c|c|c|c|c|c|c|c|c|}
\hline \multirow[t]{2}{*}{$\begin{array}{c}\text { Bacteria } \\
\text { (N) tested }\end{array}$} & \multicolumn{14}{|c|}{ N (\%) Susceptible to: } \\
\hline & AMK & $\begin{array}{l}\text { AMPI } \\
\text { SAM }\end{array}$ & CFZ & CTX & CIP & ERY & GEN & MEM & OXA & PEN & TZP & RIF & TMP & VAN \\
\hline E. coli (28) & $\begin{array}{c}4 \\
(14)\end{array}$ & $\begin{array}{c}9 \\
(32)\end{array}$ & $\begin{array}{c}5 \\
(18)\end{array}$ & $\begin{array}{c}8 \\
(28)\end{array}$ & $\begin{array}{c}0 \\
(0)\end{array}$ & $\begin{array}{c}0 \\
(0)\end{array}$ & $\begin{array}{c}14 \\
(50)\end{array}$ & $\begin{array}{c}3 \\
(11)\end{array}$ & $\begin{array}{c}0 \\
(0)\end{array}$ & $\begin{array}{c}0 \\
(0)\end{array}$ & $\begin{array}{c}8 \\
(29)\end{array}$ & $\begin{array}{c}0 \\
(0)\end{array}$ & $\begin{array}{c}4 \\
(14)\end{array}$ & $\begin{array}{c}0 \\
(0)\end{array}$ \\
\hline $\begin{array}{l}\text { Klebsiella } \\
(12)\end{array}$ & $3(25)$ & $\begin{array}{c}7 \\
(58)\end{array}$ & $\begin{array}{c}4 \\
(33)\end{array}$ & $\begin{array}{c}8 \\
(67)\end{array}$ & $\begin{array}{c}0 \\
(0)\end{array}$ & $\begin{array}{c}0 \\
(0)\end{array}$ & $\begin{array}{c}12 \\
(100)\end{array}$ & $\begin{array}{c}2 \\
(17)\end{array}$ & $\begin{array}{c}0 \\
(0)\end{array}$ & $\begin{array}{c}0 \\
(0)\end{array}$ & $\begin{array}{c}4 \\
(33)\end{array}$ & $\begin{array}{c}0 \\
(0)\end{array}$ & $\begin{array}{c}2 \\
(17)\end{array}$ & $\begin{array}{c}0 \\
(0)\end{array}$ \\
\hline $\begin{array}{l}\text { S. aureus } \\
\text { (10) }\end{array}$ & $1(10)$ & $\begin{array}{c}5 \\
(50)\end{array}$ & $\begin{array}{c}2 \\
(20)\end{array}$ & $\begin{array}{c}4 \\
(40)\end{array}$ & $\begin{array}{c}9 \\
(90)\end{array}$ & $\begin{array}{c}9 \\
(90)\end{array}$ & $\begin{array}{c}3 \\
(30)\end{array}$ & $\begin{array}{c}1 \\
(10)\end{array}$ & $\begin{array}{c}10 \\
(100)\end{array}$ & $\begin{array}{c}3 \\
(30)\end{array}$ & $\begin{array}{c}10 \\
(100)\end{array}$ & $\begin{array}{c}5 \\
(50)\end{array}$ & $\begin{array}{c}3 \\
(30)\end{array}$ & $\begin{array}{c}10 \\
(10)\end{array}$ \\
\hline
\end{tabular}

AMK: Amikacin; Ampicillin+ sulbactam: AMP/SAM; Cefazolin: CFZ; Cefotaxime: CTX; Ciprofloxacin ; CIP; Clindamycin: CLI; Erythromycin: ERY; Gentamycin: GEN; Imipinem: IPM; Meropnem: MEM; Oxacillin: OXA; Penicillin: PEN; Piperacillin/tazobactam: TZP; Rifampicin: RIF; Trimethoprim: TMP; Vancomycin: VAN. 
Table 4. Comparison of clinical and demographic characteristics for SBP and non SBP

\begin{tabular}{|c|c|c|c|}
\hline Characteristics & $\begin{array}{c}\text { SBP } \\
\mathrm{No}=106\end{array}$ & $\begin{array}{c}\text { Non SBP } \\
\text { No }=83\end{array}$ & Significance \\
\hline Age(years):mean \pm SD (Range) & $61.5 \pm 14.5(30-94)$ & $58.7 \pm 10.7(36-89)$ & $0.13^{*}$ \\
\hline $\begin{array}{l}\text { Male: N (\%) } \\
\text { Female: N (\%) }\end{array}$ & $\begin{array}{l}64(54.2) \\
42(59.2)\end{array}$ & $\begin{array}{l}54(45.8) \\
29(40.8)\end{array}$ & $0.5^{\star *}$ \\
\hline Smokers: N (\%) & $35(52.2)$ & $32(47.8)$ & $0.47 \star \star$ \\
\hline MELDscore:mean $\pm S D$ (Range) & $21.8 \pm 9.2(8-45)$ & $20.6 \pm 10.3(6-54)$ & $0.38^{*}$ \\
\hline Associated infection: N (\%) & $51(58.6)$ & $36(41.4)$ & $0.51 * *$ \\
\hline Random blood glucose (mgldl):mean \pm SD & $193.5 \pm 114$ & $172.8 \pm 92$ & $0.1^{*}$ \\
\hline $\begin{array}{l}\text { Risk factors: } \mathbf{N}(\%) \\
\text { HCC } \\
\text { PPI } \\
\text { BB } \\
\text { Diabetes }\end{array}$ & $\begin{array}{c}48(63.6) \\
6(50) \\
15(36.6) \\
35(52.2)\end{array}$ & $\begin{array}{c}23(32.4) \\
6(50) \\
26(63.4) \\
32(47.8)\end{array}$ & $\begin{array}{c}0.013^{* *} \\
0.66^{* *} \\
0.004^{* *} \\
0.42 * *\end{array}$ \\
\hline $\begin{array}{l}\text { Complaint: } \mathbf{N}(\%) \\
\text { Fever: } \\
\text { Abdominal pain } \\
\text { G I bleeding } \\
\text { H.E. } \\
\text { Hypotension at presentation: N (\%) }\end{array}$ & $\begin{array}{c}61(69.3) \\
48(61.5) \\
9(39.1) \\
21(50) \\
10(32.3)\end{array}$ & $\begin{array}{c}27(30.7) \\
30(38.5) \\
14(6.09) \\
21(50) \\
21(67.7)\end{array}$ & $\begin{array}{c}0.001 * * \\
0.2 * * \\
0.08 * * \\
0.36 * * \\
0.003 * *\end{array}$ \\
\hline Child-pugh score: mean \pm SD(Range) & $9.6 \pm 2.3(7-15)$ & $9.7 \pm 2.3(7-15)$ & $0.64^{*}$ \\
\hline Prothrombin time(seconds):mean \pm SD & $18.1 \pm 7.6$ & $17.1 \pm 5.1$ & $0.09 *$ \\
\hline INR: mean $\pm S D$ & $1.4 \pm 0.6$ & $1.5 \pm 0.5$ & $0.42 * *$ \\
\hline
\end{tabular}

Abbreviations; MELD: Model for End stage Liver Disease, PPI: proton pump inhibitor, HCC: hepatocellular carcinoma, BB: beta blocker, Gl: gastro-intestinal, HE: hepatic encephalopathy, Level of significance calculated $b$ *: $t$ - test **: $X^{2}$ test

However, it is to be emphasized that the etiology of gram positive cocci in SBP has markedly increased recently.Streptococci (mostly pneumococci), have been found to be common organisms in patients who are not receiving selective intestinal decontamination [18]. S. aureus is an emergent bacteria in patients who have been treated with antibiotic prophylaxis (quinolones) and/or underwent invasive procedures [19-20]. S. aureus accounted for $20 \%$ of isolated organisms in the present work, which is comparable to other studies [19], but is less than report given by Fernandez et al., [20]. No obligate anaerobes were isolated as in other studies. The reduced capability of intestinal anaerobes for translocation and the relatively high oxygen content of ascitic fluid are considered inhibiting factors [21].
Reputable organizations have recommended several antibiotics that might be used for empirical treatment in community based SBP. In a nosocomial setting patient should receive empiric antibiotic therapy according to the local susceptibility of bacteria. This is of particular concern due to recent changes in the microbial flora of SBP, and increased incidence of antibiotic- resistant gram-negative bacteria mostly due to the widespread usage of quinolones for prophylaxis. With appropriate antibiotic treatment of SBP, infection-related mortality can approach zero [22].

Hepatocellular carcinoma was identified as a risk factor; an anticipated issue due to the negative effect of HCC on the immune system.

We found no relation between prior use of 
Table 5. Comparison of clinical and demographic characteristics for SBP variants

\begin{tabular}{|c|c|c|c|}
\hline Characteristics & $\begin{array}{c}\text { Classic SBP } \\
\text { No }=50\end{array}$ & $\begin{array}{l}\text { CNNA } \\
\text { No }=56\end{array}$ & Significance \\
\hline Age(years):mean \pm SD & $61.7 \pm 14$ & $61.4 \pm 15.2$ & $0.91 *$ \\
\hline $\begin{array}{l}\text { Male: N (\%) } \\
\text { Female: N (\%) }\end{array}$ & $\begin{array}{l}31(62) \\
19(38)\end{array}$ & $\begin{array}{l}33(58.9) \\
23(41.1)\end{array}$ & $0.74^{* *}$ \\
\hline Smoking: N (\%) & 19(38) & $40(71.4)$ & $0.3^{* *}$ \\
\hline $\begin{array}{l}\text { Risk factors: } \mathbf{N}(\%) \\
\text { HCC } \\
\text { PPI } \\
\text { BB } \\
\text { Diabetes }\end{array}$ & $\begin{array}{c}15(30) \\
5(10) \\
9(18) \\
17(34)\end{array}$ & $\begin{array}{c}33(58.9) \\
1(1.8) \\
6(10.7) \\
18(32.1)\end{array}$ & $\begin{array}{c}0.002^{* *} \\
0.15^{* *} \\
0.28^{* *} \\
0.83^{* *}\end{array}$ \\
\hline Child-pugh score: mean \pm SD & $9.5 \pm 2.2$ & $9.6 \pm 2.3$ & $0.81 *$ \\
\hline $\begin{array}{l}\text { Complaint: } \mathbf{N}(\%) \\
\text { Fever } \\
\text { Abd. Pain } \\
\text { G I bleeding } \\
\text { HE } \\
\text { Hypotension at presentation }\end{array}$ & $\begin{array}{c}19(38.0) \\
9(18.0) \\
4(8) \\
13(26) \\
6(12)\end{array}$ & $\begin{array}{c}42(75) \\
39(69.6) \\
5(8.9) \\
8(14.3) \\
4(7.1)\end{array}$ & $\begin{array}{l}0.001^{* *} \\
0.001^{* *} \\
0.85^{\star *} \\
0.13^{* *} \\
0.6 * *\end{array}$ \\
\hline Associated infections: N (\%) & $23(46.0 \%)$ & $28(50)$ & $0.67 * *$ \\
\hline Random blood sugar(mg/dl):mean \pm SD & $188.9 \pm 113$ & $197.7 \pm 115.2$ & $0.69 *$ \\
\hline Total protein(g/dl):mean \pm SD & $1695.5 \pm 1081$ & $1608 \pm 1321$ & $0.71 *$ \\
\hline Total leucocytic count(cells/ul):mean \pm SD & $1136 \pm 667$ & $1767.3 \pm 1814$ & $0.02 *$ \\
\hline Prothrombin time(seconds):mean \pm SD & $17.9 \pm 5.7$ & $19.5 \pm 9.0$ & $0.29 *$ \\
\hline INR: mean \pm SD & $1.52 \pm 0.7$ & $1.36 \pm 0.5$ & $0.19 *$ \\
\hline $\mathrm{LDH}(\mathrm{IU} / \mathrm{I}): \mathrm{mean} \pm \mathrm{SD}$ & $211.2 \pm 161$ & $159.0 \pm 164.1$ & $0.1^{*}$ \\
\hline Glucose(mg/dl):mean \pm SD & $192 \pm 153$ & $197.7 \pm 115.2$ & $0.69 *$ \\
\hline Neutrophilcount(cells/ $\mu$ l):mean \pm SD & $865.7 \pm 527$ & $897.4 \pm 813.7$ & $0.815^{\star}$ \\
\hline
\end{tabular}

Abbreviations; MELD: Model for End stage Liver Disease, PPI: proton pump inhibitor, HCC: hepatocellular carcinoma, BB: beta blocker, GI: gastro-intestinal, HE: hepatic encephalopathy

Level of significance calculated by

$*$ : $t$ - test, $* *$ : $X^{2}$ test

proton pump inhibitor (PPI) and SBP as reported by similar studies [23]. Additionally, patients using Beta blockers (BBS) were less liable to develop SBP; however such medication had nothing to do as a differentiating factor for presenting with a specific SBP variant. BBS prevent variceal bleeding through decreasing portal pressure which is theoretically supposed to benefit patients. Reducing portal hypertension may decrease intestinal translocation of microorganisms into the peritoneal cavity [25]. In contrast, other studies have identified Beta blockers use as an independent risk factor for death [26].
These contradictory conclusions require more investigations before BBS use can be endorsed for the routine management of ascites.

Fever and hypotension were significantly associated with diagnosis of SBP among our patients. Contrary to earlier studies, abdominal pain was a symptom significantly associated with the CNNA. Total leukocytic count is significantly higher in CNNA than classic type. This result could lead to better ability of ascetic fluid to remove bacteria leading to the CNNA variant, a finding that needs further studies. 
When analyzing data for outcomes of SBP versus non-SBP, a higher mortality rate in patients with the SBP was evident, and it was consistent with the other findings [27]. Mortality rates of SBP cases are vary between $20 \%$ to $70 \%$ [28]. Mortality being generally due to complications such as acute variceal bleeding, development of the hepatorenal syndrome or progressive liver failure. With advances in diagnosis and treatment, mortality from SBP is expected to be decreasing. Risk factors of mortality among SBP patients were analyzed using multivariate regression model. Age and MELD score were the only independent risk factors for such events, and this finding is much similar to other reports [29]

\section{Conclusions}

Spontaneous bacterial peritonitis is occurring at high frequency among cirrhotic patients admitted to the Medical ICU of Zagazig University hospital. This serious complication should be detected without delay, since prompt diagnosis and treatment result in decreased morbidity and mortality among infected patients. This study provides guidelines for selecting antibiotics for empirical therapy of patients with SBP in our hospital and region.

\section{References}

1. Stiburek O, Kopacova M, Lata J. Spontaneous bacterial peritonitis: a severe complication of liver cirrhosis. World J Gastroentero 2009; 2(5): 3 -9|

2. Gaya DR, David B, Lyon $T$, et al .Bedside leucocyte esterase reagent strips with spectrophotometric analysis to rapidly exclude spontaneous bacterial peritonitis: apilot study. Eur J Gastroenterol Hepatol 2007; 19: 289-295.

3. Koulaouzidis A, Bhat S, Saeed AA. Spontaneous bacterial peritonitis. World J. Gastroenterol. 2009; 15 (9): 1042-9.

4. Navasa M, Rodes J. Management of ascites in the patient with portal hypertension with emphasis on spontaneous bacterial peritonitis. Semin Gastrointest Dis 1997; 8(4): 200-9

5. Riggio O, Angeloni S. Ascitic fluid analysis for diagnosis and monitoring of spontaneous bacterial peritonitis. World J Gastroenterol 2009;15(31): 3845-50.
6. Acevedo J, Fernandez J, Castro M, et al. Current efficacy of recommended empiric therapy in patients with cirrhosis and bacterial infection. J Hepatol 2009; 50 suppl: 1: 55

7. Gines $P$, Rimola A, Planas $R$, et al. Norfloxacin prevents spontaneous bacterial peritonitis recurrence in cirrhosis: results of a double -blind placebo-controlled trial. Hepatology 1990; 12: $716-24$.

8. Child CG, Turcotte JG. Surgery and portal hypertension. Major Probl Clin Surgery 1964;1:1-85

9. Clinical and Laboratory Standards Institute (CLSI): Body fluid analysis for cellular composition, approved guideline. CLSI document H56-A, Wayne, PA, 2006.

10. Clinical and Laboratory Standards Institute (CLSI). Performance standards for antimicrobial susceptibility testing. 23nd Informational Supplement. M100-S23. Wayne, PA: CLSI, 2013.

11. Iqbal S, Iman N, andAlam N. Incidence of spontaneous bacterial peritonitis in liver cirrhosis, the causative organisms and antibiotic sensitivity. JPMI 2004; 18:614-9

12. Saqib A, Masood Z Khan RR, Haque I. Frequency of spontaneous bacterial peritonitis in cirrhotic patients with ascites due to hepatitis B and C. JUMDC 2012;3(1)22-3.

13. Amjad Z, Rahida K, Rashid M, et al. Frequency and microbial spectrum of Spontaneous bacterial peritonitis in established cirrhotic liver. J Ayub Med Coll Abbottabad 2011; 32(4):15-17.

14. Nepal N, Pande PR, Khatri R. Study of frequency of spontaneous bacterial peritonitis in patients with alcoholic cirrhosis with ascites. Postgrad Med J NAMS 2009; 9(2)45-49.

15. Bandy SM, Tuttle A. Spontaneous bacterial peritonitis. E-medicine from WebMD. Updated July 16, 2008.Last cited Dec 25th 2015

16. Bhuva M, Ganger D, Jensen D. Spontaneous bacterial peritonitis: An update on evaluation, management, and prevention. Am J Med 1994;97:169-75

17. Sheer TA, Runyon B.A. Spontaneous bacterial peritonitis. Dig Dis 2005; 23(1): 39-46.

18. Garcio-Tsao G. Bacterial infection in Cirrhosis: treatment and prophylaxis. J Hepatol 2005;42(S): 585-92

19. Such J, Runyon A. Spontaneous bacterial peritonitis. Clin Infect Dis 1998;27:669-76

20. Fernandez J, Navasa M, Gomez J. et al. Bacterial infections in cirrhosis: Epidemiologic changes with invasive procedures and norfloxacin prophylaxis. Hepatology 2002; 35:140-48.

21. Scheckman $P$, Onderdonk $A B$, Bartlett JG. Anaerobes in spontaneous peritonitis (letter) Lancet 1977; 2:1223

22. Lolekha P, Chunlertrith K. Spontaneous bacterial peritonitis, causes and antibiotic usage in Srinagarind hospital. J Med Assoc Thai 2001;84(7):995-9

23. Sersté $T$, Melot C, Francoz C, Durand F, et al. Deleterious effects of beta-blockers on survival in patients with cirrhosis and refractory ascites. Hepatology. 2010;52:1017-22.

24. RatelleM, Perreault S, Villeneuve JP, Tremblay L. Association between proton pump inhibitor use and spontaneous bacterial peritonitis in cirrhotic patients with ascites. Can J Gastroenterol Hepatol 2014 ; 28(6): 330-34

25. Hernández-Gea V, Aracil C, Colomo A, et al. Development of ascites in compensated cirrhosis with severe portal hypertension 
treated with beta;-blockers. Am J Gastroenterol 2012;107:41827.

26. De Vos M, De Vroey B, Garcia Garcia B, et al. Role of proton pump inhibitors in the occurrence and the prognosis of spontaneous bacterial peritonitis in cirrhotic patients with ascites. Liver Int 2013;33:1316-23

27. Bankar S, De A and Baveja S. Comparison of three culture methods for diagnosis of Spontaneous Bacterial Peritonitis (SBP) in adult patients with cirrhosis Int J Curr Microbiol App Sci 2014.3(7): 156-160

28. Thanopoulou AC, Koskinas JS, Hadziyannis SJ. Spontaneous bacterial peritonitis (SBP):clinical, laboratory, and prognostic features. A single-center experience. Eur J Intern Med. 2002;13(3):194-8.

29. Thiele GB, Silva OM , Fayad L, LazzarottoC, Ferreira MA, Marconcini M L et al., Luz. Clinical and laboratorial features of spontaneous bacterial peritonitis in southern Brazil. Sao Paulo Med J (2014): 132(4), 205-10. https://dx.doi.org/ 10.1590/15163180.2014 .1324698

\section{Comment on this article:}
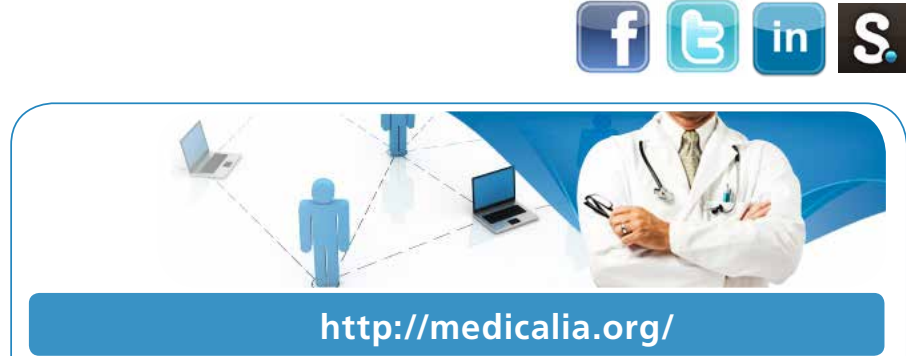

Where Doctors exchange clinical experiences, review their cases and share clinical knowledge. You can also access lots of medical publications for free. Join Now!

\section{Publish with iMedPub}

http://www.imed.pub

The Journal is an open access peer-reviewed journal that publishes scientific papers about all aspects of antimicrobials. The journal will publish original research articles, reviews, brief reports and case reports dealing with basic and clinical antibacterial agents, antiviral, antiprotozoals, antituberculuous, antifungal and antihelminthes agents.

All manuscripts must be prepared in English, and are subject to a rigorous and fair peer-review process. Accepted papers will immediately appear online.

The journal aims to advance the knowledge, attitude and the research of chemotherapy in the Arabic world in cooperation with international, national scientific and public societies as well as research centers with similar aims and objectives. 